\title{
バイオベースファイバー・ポリマー
}

\section{Biobased Fibers and Polymers}

\section{1.はじめに}

21 世紀になって人間の生産活動の持続性 (sustainability) がクローズアップされてくるとともに、環境保全、省資源、 省エネルギー、リサイクルなどあらゆる面で新思考に基づ く持続性社会への移行が検討されるようになった。特に、 エネルギー・資源の観点から、有限の化石資源を再生可能 資源( renewable resource) へ転換して、極度の石油依存か らの脱却が図られようとしている。バイオマス (biomass) は、もともと植物が光合成により大気中の二酸化炭素を同 化して作り上げたものであるため、その利用後に廃棄处理 をしても大気に新たな二酸化炭素の負荷を与えることには ならない。このため、バイオマスを循環利用する生産社会 では、生産一廃棄による環境破壊を伴うことなく持続的な 生産を恒久的に維持することができると考えられている。 このように、最終処分の段階で環境中の二酸化炭素を増や さない性格に対して「カーボンニュートラル」)もしくは 「high-carbo diet ${ }^{2)}$ というキャッチコピーが当てられるよ うになったが、これらは地球温暖化現象の主因と考えられ る二酸化炭素の大気濃度の上昇を軽減する運動への理解を 促進するために用いられている。

素材面でも、石油化学製品からバイオマスを中心とする 天然素材へのシフト、すなわち持続性材料 (sustainable materials)の開発が進められている。このような動きに呼 応して、(1)未利用のバイオマス資源の開拓、(2)バイオマ スリファイナリー(biomass refinery)による新基礎化学原 料の開発、(3) 新しいバイオマスプラスチック、複合材料 の開発等が重要な課題となってきている。しかしながら、 現在の技術ではバイオマスの効率的利用は困難であり、そ の利用を進めるには新技術の開拓、すなわち、21世紀の 中心になるであろうバイオ技術を利用した大規模バイオイ ンダストリー(bio-industry)あるいはバイオマスベース産 業(biomass-based industry)とも言うべき産業の確立が重

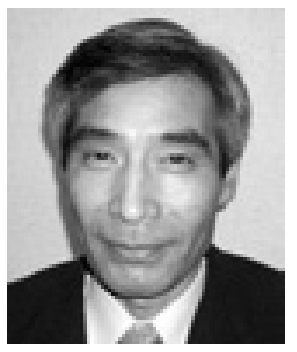

YOSHIHARU KIMURA

京都工芸䋐維大学 大学院 工芸科学研 究科 生体分子工学部門 教授 同大学 繊維科学センター長 繊維学会 副会長 工学博士 E-mail : ykimura@kit.ac.jp 〈専門〉高分子材料化学、繊維科学 〈趣味〉ゴルフ、囲碁
要となってくる。繊維・高分子の技術開発に扎いてもこの 大きな流れから逃れるべくもなく、新たな変革が求められ てくる。

\section{2. バイオマスのケモ・バイオ変換と バイオベースマテリアル}

バイオマスを素材原料として目的物に誘導していく過程 では、エネルギーを節約しながら副生物による環境污染を 防ぐ新たな生産方式の開発が不可欠である。そのためには、 これまでの熱化学的変換にのみ依拠するのではなく、温和 で効率的な生物反応によるバイオ変換を巧みに利用した新 しい生産プロセスが必要となる。このプロセスでは、バイ オプロセスを軸に従来の化学プロセスを組合せて目的物を 得るところに特徴があり、筆者はこのようなプロセスを「ケ モ・バイオプロセス (chemo-bio process)」と名づけてい る3)。また、この新しいプロセスを用いてバイオマスから 合成される材料をバイオベースマテリアル (biobased materials) と総称している4)。

図1に、典型的なバイオマスの材料化プロセスを示す。 高分子状のバイオマスをまず低分子原料にブレークダウン し、その後に適当な変換過程を経ながら、必要に応じて再 びポリマー化するのが最も効率的とされる5)。バイオマス を直接ポリマーとして利用しようとすると、多くの場合、 精製工程に多大な労力と費用を費やすこととなり、かえっ てコスト増を引き起こす。そのため、精製の容易な低分子 原料へのブレークダウンが不可欠であり、また、その方が 大量生産によるコストダウンも図りやすい。その代表例は ポリ乳酸の製造に見ることができる。図 2 に示すように、 デンプンを糖化後、生物発醅して乳酸を合成し、続いて化 学的な重合によりポリ乳酸の合成が行われる。このように、 生物の代謝経路を巧みに利用しながら、バイオマスの化学 原料化を図るプロセスがバイオマスリファイナリーであり、 バイオベースマテリアルの基本製造プロセスとなる。ここ では微生物の司る糖や脂肪酸代謝を活用した変換反応が、 分解だけでなく有用物質の合成にも応用される。しかしな がら、現在の技術で効率的にブレークダウンできるバイオ マスは数少なく、デンプンの酵素加水分解によるグルコー ス化が工業的規模で実施されている唯一のバイオプロセス である。今後、デンプン以外のバイオマス、特にセルロー スに対しても、効率的でかつ環境対応のバイオマスリファ 


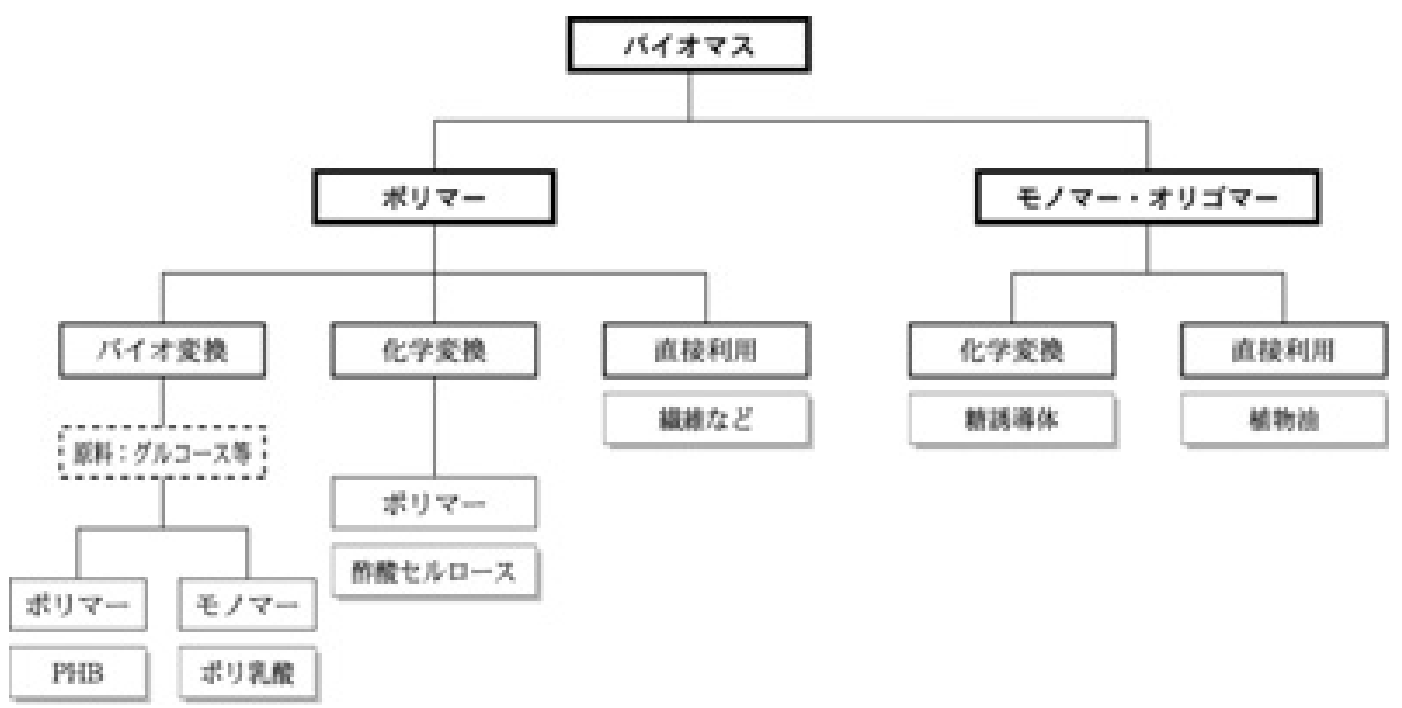

図 1 バイオマスの材料化プロセス

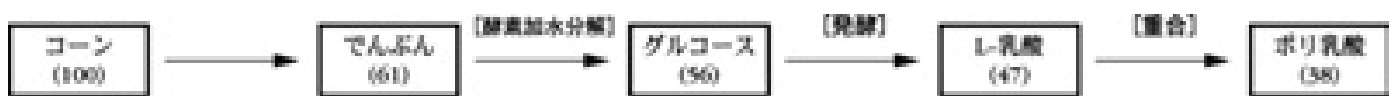

図 2 コーンを原料とするポリ乳酸の合成(重量\%)

イナリーが行われていくであろう。

\section{3. バイオマス由来の新基礎化学物質}

最近、バイオマスリファイナリーによって合成が期待で きる 12 種の基礎化学物質 (platform chemicals)が米国で報 告された6)。それらを表 1 に示す。12 種のうち 8 種はカル ボン酸誘導体であることが分かる。現在のところ、どのよ うなバイオマス変換プロセスを経てこのような物質が誘導 されるのかは確定していないが、これらを出発原料にして 化学変換を加えて材料化もしくは高分子化されて実用に供 される。 8 種のカルボン酸誘導体に対して予測されている コスト、用途、市場規模を表 2 に示す。特に、レブリン酸 (levulinic acid)、グルカリン酸 (glucaric acid)、フランジカ
ルボン酸 (2,5-furandicarboxylic acid)などに対する予測生産 量が大きい。いずれも樹脂原料としての期待值であり、こ れらの材料化プロセスがどのように開発されるのか興味深 いし、また、直近の重要な研究開発対象となるであろう。

ケモ・バイオ変換では、微生物の有する機能、すなわち 生物の 1 次、 2 次代謝を積極的に利用する必要がある。罒 3 に微生物の示す糖の代謝プロセスを示す。このスキーム からどのような有用化合物が糖代謝の中間生成物として取 り出すことができるかが類推できる。上述のバイオマスリ ファイナリーで有望視されているコハク酸やアセト酢酸 ( $\beta$-ブチロラクトンに変換) などの $\mathrm{C} 4$ 化合物だけでなく、 基礎化学物質には入っていない乳酸やトリメチレングリ コールなどの C3 化合物の合成も糖代謝により可能である

表 1 バイオマスリファイナリーにより合成が有望とされる基礎化学物質 (12 種)

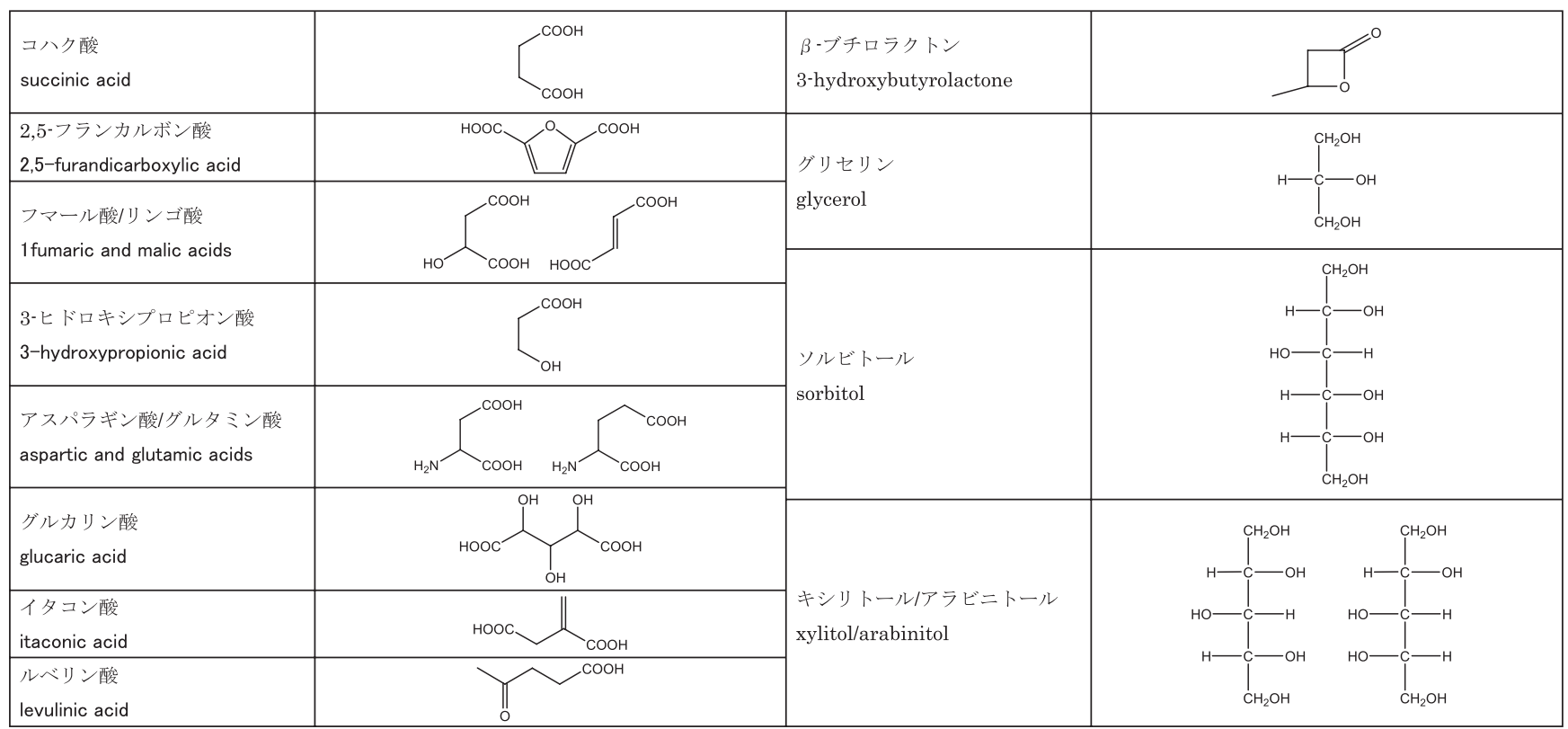


表 2 基礎化学物質となる 8 種のカルボン酸類の用途展望

\begin{tabular}{|c|c|c|c|}
\hline Commodity Chemical & $\begin{array}{l}\text { 価格 } \\
(\$ / \mathrm{kg})\end{array}$ & $\begin{array}{c}\text { 市場 } \\
\left(10^{6} t / y\right)\end{array}$ & 主要な誘導体 \\
\hline succinic acid & 1.1 & 0.015 & $\begin{array}{l}\text { 医薬、食品、界面活性剂 } \\
\text { 繊維、プラスチック }\end{array}$ \\
\hline 2,5-furandicarboxylic acid & $1.87-6.61$ & 5.9 & $\mathrm{PET} \cdot \mathrm{PBT}$ ·ナイロン原料 \\
\hline fumaric and malic acids & & $\left(5.8 \times 10^{9}\right)^{\mathrm{a}}$ & 食品添加物 \\
\hline 3-hydroxypropionic acid & & $\left(70 \times 10^{9}\right)^{a}$ & $\begin{array}{l}\text { アクリル酸、アクリルアミド } \\
\text { プロピレングリコール }\end{array}$ \\
\hline aspartic and glutamic acids & 8.01 & 0.5 & サプリメント、ポリマー \\
\hline glucaric acid & $1.87-4.85$ & 4.1 & $\begin{array}{l}\text { 界面活性剂、サプリメント } \\
\text { 高分岐ポリエステル }\end{array}$ \\
\hline itaconic acid & 1.83 & 0.8 & アクリル樹脂、SBR \\
\hline levulinic acid & $2.86-6.61$ & 14.0 & $\begin{array}{l}\text { アクリル樹脂、ポリカーボネート } \\
\text { 除草剂 }\end{array}$ \\
\hline
\end{tabular}

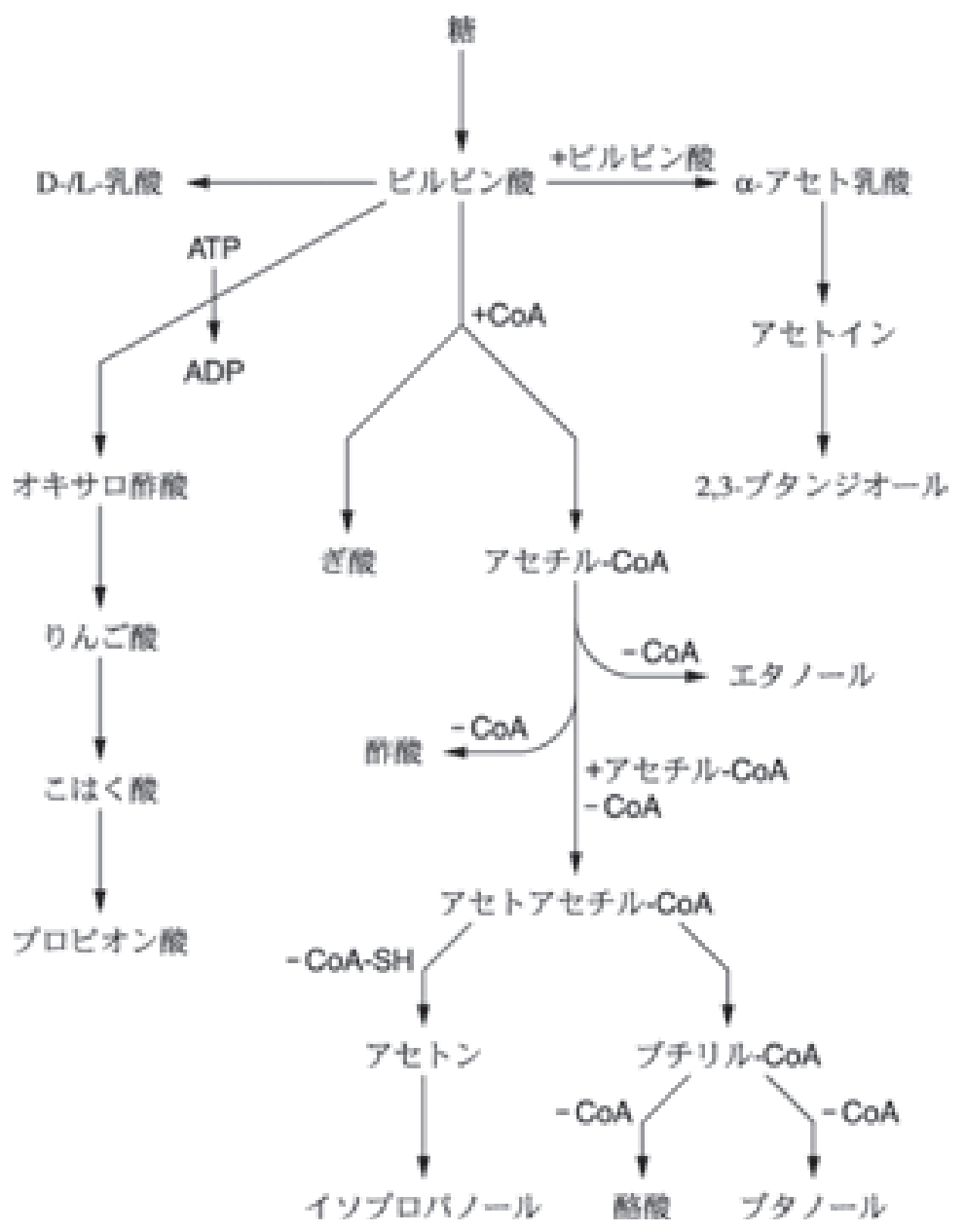

図 3 微生物による糖代謝

ことが分かる。実際に、乳酸とトリメチレングリコールは 発酵による工業生産が現在行われている。

\section{4. バイオベースポリマーの分類}

バイオマスを出発原料に用いて生産されるポリマー類を バイオベースポリマー(biobased polymers)とよび、それ を用いたプラスチックをバイオベースプラスチック (biobased plastics)、もしくは「バイオマスプラスチック」、
「バイオプラスチック」とよんでいる7)。バイオマスプラ スチックはバイオベースプラスチックとほとんど同義語で あるが、原料に石油や天然ガス由来のメタノールを用いて 微生物合成されるポリマーはバイオベースプラスチックの 中に入るのに対してバイオマスプラスチックの範疇で捉え ることはできない。したがって、バイオベースポリマーの 方が、より広い範囲をカバーする。

バイオベースポリマーはその製造過程の違いにより、表 
表 3 バイオベースポリマーの分類

\begin{tabular}{|c|c|c|c|}
\hline 種類 & ポリマー & 例 & 原料 \\
\hline $\begin{array}{l}\text { 天然系 } \\
\text { (高分子) }\end{array}$ & $\begin{array}{l}\text { 多糖 } \\
\text { タンパク } \\
\text { 核酸 } \\
\text { 天然ゴム } \\
\text { リグニン } \\
\text { シェラック }\end{array}$ & $\begin{array}{l}\text { アミロース } \\
\text { セルロース、デキストラン } \\
\text { フィブロイン、ケラチン、 } \\
\text { コラーゲン } \\
\text { ポリイソプレノイド }\end{array}$ & $\begin{array}{l}\text { デンプン } \\
\text { パルプ、綿、麻 } \\
\text { 絹、羊毛、羽毛、牛皮 } \\
\text { 白子 } \\
\text { ゴムの木 }\end{array}$ \\
\hline (低分子) & $\begin{array}{l}\text { 脂質 } \\
\text { 多糖由来物質 } \\
\text { らるし }\end{array}$ & {$\left[\begin{array}{l}\text { 油脂 } \\
\text { ポリフェノール }\end{array}\right.$} & 植物油、動物油 \\
\hline バイオ合成系 & $\begin{array}{l}\text { ポリエステル } \\
\text { セルロース } \\
\text { ペプチド }\end{array}$ & 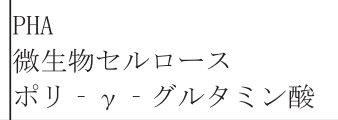 & 糖 \\
\hline ケモ・バイオ系 & $\begin{array}{l}\text { ポリエステル } \\
\text { ビニルポリマー }\end{array}$ & $\begin{array}{l}\text { ポリ乳酸、PBS } \\
\text { PTT } \\
\text { PMBL }\end{array}$ & $\begin{array}{l}\text { 乳酸、コハク酸、 } \\
\text { トリメチレングリコー } \\
\text { ル } \\
\text { チューリパリン }\end{array}$ \\
\hline 化学変換系 & $\begin{array}{l}\text { 酢酸セルロース } \\
\text { エポキシ化油脂 }\end{array}$ & & $\begin{array}{l}\text { セルロース } \\
\text { 油脂 }\end{array}$ \\
\hline
\end{tabular}

PBS：ポリコハク酸ブチレン； PTT：ポリテレフタール酸トリメチレン；

PMBL ポリ ( $\alpha$-メチレン- $\gamma$-ブチロラクトン) ; PHA : ポリヒドロキシアルカン酸

3 のように分類される。天然系 (natural)素材は、バイオマ スから得られる高分子素材をそのまま活用するものと天然 から得られる低分子物質を樹脂化して利用するものとに分 けることができる。バイオ合成系(biosynthetic)素材は微 生物発酵や植物への遺伝子導入 (transgenic plant)などバイ オテクノロジーの手法を駆使して合成されてくるポリマー である。それに対して、ケモ・バイオ系 (chemo-bio syntheic)の素材は、バイオマスをブレークダウンした素 材を原料に用いて化学的に重合される高分子素材で、上述 のケモ・バイオ変換過程を経て合成されるものである。化 学変換 (chemical modification)系は天然系素材を化学的に 改変して利用するものであり、バイオマスのブレークダウ ンを経由するものではない。一方、プランテーションによっ て大規模生産されてくるバイオマスはバイオマスエネル ギーとして利用することが中心となるが、繊維状のバイオ マスそのものをパルプや補強用の繊維素材として大量に利 用することも考えられている。

\section{5. 生分解性ポリマーとの関連}

生分解性ポリマー (biodegradable polymer) は、自然界や 生体の作用で分解して炭酸ガスや水などの地球物質に無機 化 (assimilation) される有機材料であり、環境に適合した 理想的な材料として開発されてきた8,9)。生分解性ポリマー は、その分解特性を考慮すると「代謝生成物を分解可能な 結合でつなぎ合わせた高分子化合物」と定義され、この定 義に沿って多くのポリマーの分子設計、スクリーニングが 行われた。この概念は、とりもなおさず再生可能な生物資 源を利用する「グリーン・サステナブル・ケミストリー (GSC： green sustainable chemistry)」の基本方針と軌を
一にしており、バイオベースポリマーの定義とも大きな違 いはない。ただ、バイオベースポリマーでは生分解しない ものも多くあり、ポリマーが生分解するか否かは問題とは ならない。

表 4 に、これまでに生分解性ポリマーとして開発されて きた高分子材料が歴史的に有することとなった三つの性格 を比較した。生分解性プラスチックでは特定の試験による 生分解性の保持が不可欠であるが、天然の素材からバイオ 変換されて生まれてくるバイオベースポリマー素材にはそ の性質が必然的に備わっているものが多いことにも留意し たい。これらの生分解性プラスチック、バイオベースポリ マー素材については、その用途展開の中で繊維化が検討さ れ、生分解性繊維もしくはバイオベースファイバーとして 開発が進められている。以下に、それらの新繊維素材につ いて例示してみたい。

\section{PLLA 繊維と Sc-PLA 繊維}

ポリ乳酸(PLA) はバイオマス(主としてデンプン)を出発 原料としたケモ・バイオプロセスで合成される代表的なバ イオベースポリマーである10,11)。PLAには D-乳酸、L-乳 酸を単位とするものがあり、それぞれポリ-D-乳酸 $[$ po $1 \mathrm{y}(\mathrm{D}$ -1actic acid) ; PDLA]、ポリ-L-乳酸[po1y(L-1actic acid); PLLA]とよぶ。その他、乳酸単位の D、L比(光学純度)の 異なるポリ-DL-乳酸(po1y(DL-1actic acid) ; PDLLA)、 PLLA と PDLA を混合して得られるステレオコンプレック ス型のポリ乳酸 (sc-PLA)、乳酸の D、L 連鎖をブロック状 に配置したステレオブロック型ポリ乳酸(sb-PLA)があり、 いずれも異なった性質を示す。表 5 に各種ポリ乳酸の特性 を示してある。比較のためにポリグリコール酸及びポリグ 
表 4 生分解性ポリマーの性格と適用範囲

\begin{tabular}{|c|c|c|c|}
\hline & $\begin{array}{c}\text { 第一段階 } \\
\text { (生体吸収性ポリマー) }\end{array}$ & $\begin{array}{c}\text { 第二段階 } \\
\text { (生分解性プラスチック) }\end{array}$ & $\begin{array}{c}\text { 第三段階 } \\
\text { (バイオベースポリマー) }\end{array}$ \\
\hline 目的 & 生体内吸収性 & 生分解による環境適合 & $\begin{array}{l}\text { 植物由来によるカーボンニ } \\
\text { ユートラル、再生可能資源 } \\
\text { の利用 }\end{array}$ \\
\hline 目標 & 生体の一時修復材料 & 汎用プラスチックの代替 & エンジニアリング用の代替 \\
\hline 用途 & $\begin{array}{l}\text { 医用材料、DDS } \\
\text { 手術系、骨折固定材等 }\end{array}$ & $\begin{array}{c}\text { 比較的短命な用途 } \\
\text { ゴミ袋、日用品 }\end{array}$ & $\begin{array}{l}\text { 長期に使用寸る用途 } \\
\text { 電気製品・自動車部品等 }\end{array}$ \\
\hline & ポリー $\alpha$-オキシ酸 & 脂肪族ポリエステル & ポリエステル等 \\
\hline 代表例 & $\begin{array}{l}\text { PGA, PLLA, Peptide, } \\
\text { etc. }\end{array}$ & 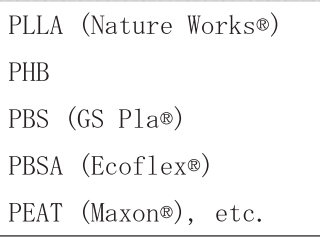 & sc-PLA, PTT, PMBL, etc. \\
\hline $\begin{array}{l}\text { 社 会 認 } \\
\text { 知 }\end{array}$ & 再生医療 & 法的インフラの支援 & 環境ブランド戦略 \\
\hline 企業化 & 1980 年から & 2000-2004 年 & $2005-2007$ 年 \\
\hline
\end{tabular}

表 5 ポリ乳酸関連ポリマーの䋊維物性

\begin{tabular}{|l|c|c|c|c|c|c|c|c|c|}
\hline & & $\begin{array}{c}\mathrm{Tm} \\
\left({ }^{\circ} \mathrm{C}\right)\end{array}$ & $\begin{array}{c}\mathrm{Tg} \\
\left({ }^{\circ} \mathrm{C}\right)\end{array}$ & $\begin{array}{c}\mathrm{Td} \\
\left({ }^{\circ} \mathrm{C}\right)\end{array}$ & $\begin{array}{c}\triangle \mathrm{Hm} \\
(\mathrm{J} / \mathrm{g})\end{array}$ & $\begin{array}{c}\mathrm{d} \\
\left(\mathrm{g} / \mathrm{cm}^{3}\right)\end{array}$ & $\begin{array}{c}\sigma \\
(\mathrm{GPa})\end{array}$ & $\begin{array}{c}\mathrm{E} \\
(\mathrm{GPa})\end{array}$ & $\begin{array}{c}\varepsilon \\
(\%)\end{array}$ \\
\hline PGA & 結晶性 & 230 & 36 & 260 & 207 & 1.69 & 1.0 & 14 & 30 \\
\hline PGLA $)^{\mathrm{a})}$ & 結晶性 & 220 & 40 & 250 & - & - & 0.8 & 8.6 & 30 \\
\hline PLLA & 結晶性 & 179 & 56 & 250 & 93,203 & 1.29 & 0.8 & 10 & 25 \\
\hline PDLLA & 非晶性 & - & 57 & & - & 1.27 & 0.05 & 0.2 & 5 \\
\hline sc-PLA & 結晶性 & 230 & 57 & 250 & 142 & & 0.6 & 10 & 30 \\
\hline
\end{tabular}

$\mathrm{Tm}$ ：融点、 $\mathrm{Tg}$ ：ガラス転移点、 $\mathrm{Td}$ ：熱分解点、 $\triangle \mathrm{Hm}$ ：融解熱量、 $\mathrm{d} ：$ 密度、 $\sigma:$ 繊維強度、 $\mathrm{E}:$ 引張弾性率、 $\varepsilon$ : 破断伸度

a) polyglactin(グリコリド/ラクチド $=9 / 1$ )、組成によって異なる

ラクチン(乳酸ーグリコール酸共重合体)の特性も併記して いる。

結晶性高分子である PLLAの融解温度は $170-180^{\circ} \mathrm{C}$ であ り、その溶融紡糸・延伸によって得られる PLLA 繊維はつ やのある美しい繊維素材となる ${ }^{12)}$ 。しかしながら、やや而 熱性が低く、高圧染色やアイロンがけには耐えない。また、 繊維強度は予想される強度 $(2 \mathrm{GPa})$ の半分以下であり、改 良の余地が残されている。それに対して、sc-PLAの結晶 融解温度は $230-240^{\circ} \mathrm{C}$ であり、PLLA や PDLAの単独ポリ マーの融点よりも $50^{\circ} \mathrm{C}$ も高い。従って、sc-PLA は耐熱性 の高い繊維素材となる可能性があり、PLLA と PDLAの溶 融混合紡糸の検討が行われてきた。その結果、PLLAと

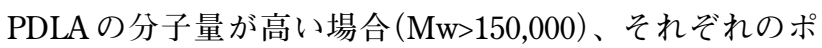
リマーの単独結晶化が生じやすく、完全な sc-PLA 䋊維が 得られにくいことが明らかとなった。最近、山根らは、溶 融紡糸で得られた PLLA/PDLA 混合繊維を 2 段延伸して 高温で緊張、ステレオコンプレックス化率の高い sc-PLA 繊維を得ることに成功した ${ }^{13)}$ 。罒 4 に山根らが報告してい る 2 段延伸時の延伸倍率とステレオコンプレックス化率の 関係を示す。 2 段延伸を $190^{\circ} \mathrm{C}$ で行うとステレオ結晶が優 先的に形成されることがわかる。このようにして得られる
ステレオコンプレックス化率の高い sc-PLA 繊維の強度は 300-500 MPa であり、通常のポリエステル繊維と同様に 120 ${ }^{\circ} \mathrm{C}$ での高圧染色(分散染料による)、 $180^{\circ} \mathrm{C}$ でのアイロンが けにも耐えることが確認された。今後、混合法の検討、結 晶核㓱の利用などにより単独結晶化を防いでステレオコン プレックス化を上昇させながらさらなる高強度化が期待さ れる。また、sc-PLAの繊維分野以外での応用も進むであ

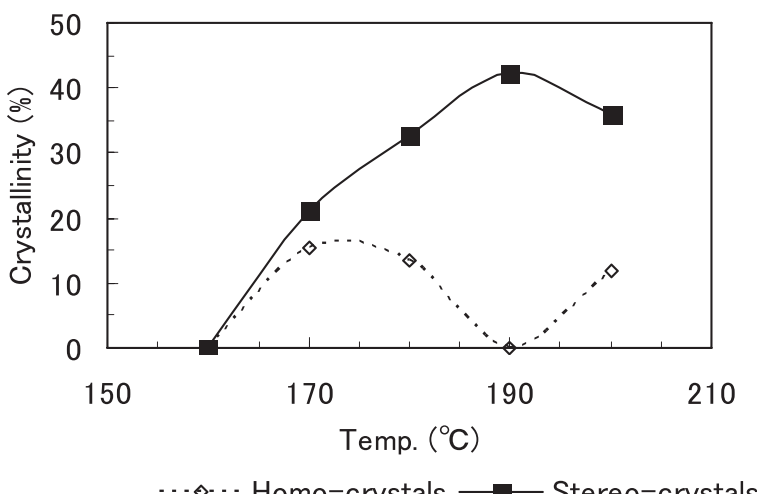

図 4 PLLA/PDLA 混合繊維の単独結晶とステレオ結晶の 結晶化度と 2 段延伸時の延伸温度との関係(第 1 段 延伸： $60^{\circ} \mathrm{C}$ で 3 倍、第 2 段延伸：各温度で 2 倍延 伸、緊張熱処理： $195^{\circ} \mathrm{C} 、 100 \mathrm{MPa} 、 3$ 分間：山 根らの報告から $\left.{ }^{13}\right)$ 


\section{PHB 繊維}

Ralstonia eutropha を用いて微生物合成されるポリヒドロ キシ酪酸 $(\mathrm{PHB})$ は $178^{\circ} \mathrm{C}$ に融点を有する熱可塑性ポリ マーであるが、結晶化度が高くて脆いという久点を有して いる。また、PHB は室温に打いて結晶間に存在する非晶 部の分子鎖が分子運動によって結晶部に取り込まれるとい う二次結晶化を起こすため、非晶部の分子鎖に張力が働い てクラックが発生しやすく、経時劣化を起こしやすい。こ のため、PHB 単独ポリマーの実用化は難しく、共重合体 化やポリマーブレンドによる実用化が検討されてきた。し かしながら、その誘導体に打いても瀻維化は容易ではな く ${ }^{14)}$ 、今のところ PHB 繊維を大量に溶融紡系することは できないと言っても過言ではない。

微生物として Aeromonas caviae を用いて脂肪酸や植物油 を炭素源として与えることによって $(R)-3$-ヒドロキシブ タン酸 (3HB) ユニットと $(R)$-3-ヒドロキシへキサン酸 $(3 \mathrm{HH})$ ユニットからなる poly (3-hydroxybutyrate-co-3hydroxyhexa-noate) (P(3HB-co-3HH)) 共重合体が合成され る ${ }^{15)}$ 。ポリマー鎖中の $3 \mathrm{HH}$ ユニットは $3 \mathrm{HB}$ 連鎖の結晶か ら離脱するため、 $\mathrm{P}(3 \mathrm{HB}-\mathrm{co}-3 \mathrm{HH})$ の結晶化度は $3 \mathrm{HH}$ 組成 の増加とともに低下する。従って、 $\mathrm{P}(3 \mathrm{HB}-c o-3 \mathrm{HH})$ は $\mathrm{PHB}$ よりずっと紡糸しやすくなる。

最近、岩田らは遺伝子組換え大腸菌を用いて分子量数百 万の超高分子量 PHB を生合成し、その繊維化に成功した。 図 5 は報告された超高分子量 PHB 繊維の引張り強度と延 伸倍率の関係をプロットしたものである ${ }^{16)}$ 。2-3 段階の延 伸により高倍率に延伸されていること、また、延伸倍率と ともに強度が増大していくことが示されている。高延伸さ れた PHB 繊維の破壊強度はポリエチレンテレフタレート (Poly (ethylene terephthalate)：PET)繊維のそれに匹敵し て抢り、この繊維では物性の経時劣化を生じないこと、ま た繊維自体が生分解性を保持していることも大きな特徴と なっている。

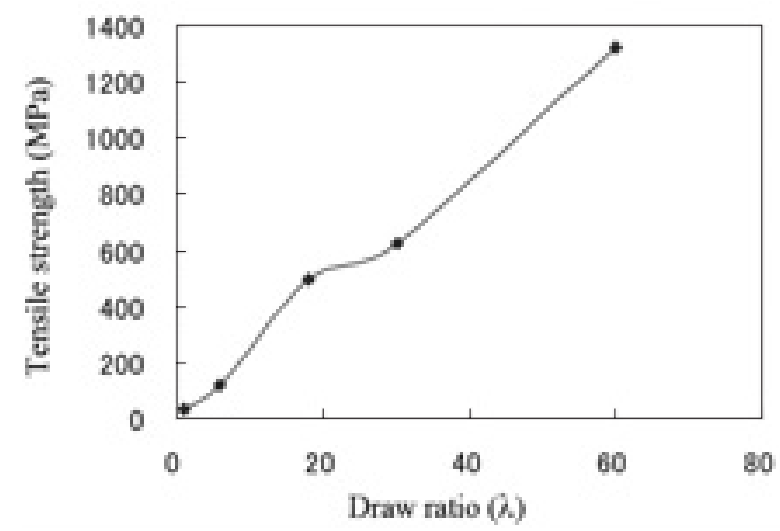

図 5 超高分子量 PHB 繊維における引張り強度の延伸倍 率依存性(岩田らのデータをプロット $\left.{ }^{16}\right)$
二成分系の脂肪族ポリエステルの中で、コハク酸とブタ ンジオールから得られるポリコハク酸ブチレン (poly(butylene succinate)：PBS)が比較的高い融点を有し、優 れた物性を有することが明らかにされた8)。この PBSに他 のカルボン酸やジオール成分、もしくはヒドロキシ酸成分 を共縮合することにより PBS の改質が行われている。例 えば、少量の L一乳酸を共縮合した (poly (butylene succinate-co-L-lactate)：PBSL)、ยーカプロラクトンを共縮 合した(poly(butylene succinate-co-hydroxycaproate) : PBSCL)、カーボネート単位を導入した(poly (butylene succinate/carbonate)：PBSC)などが工業化されている。 一方、PBSにテレフタレート単位を導入したポリコハク 酸/テレフタル酸ブチレン (poly (butylene succinate/ terephthalate)： PBST)、ポリブチレンテレフタレート (poly (butylene terephthalate) : PBT)や PETにアジピン酸 単位を導入したポリコハク酸/テレフタル酸ブチレン (poly-(butylene adipate/terephthalate) : PBAT)、ポリコハ ク酸/テレフタル酸エチレン (poly (ethylene adipate/ terephthalate)：PEAT)も工業化されている17,18)

表 6 に種々のPBS誘導体の特性を比較する ${ }^{19)}$ 。PBS は 結晶化速度が比較的速く、成形しやすいポリマーであるが、 ガラス転移点が- $30 \sim-40^{\circ} \mathrm{C}$ と低いため、繊維としてより も柔軟なフィルムとして用いられることが多い。PBS繊 維の強度は PLLA 繊維とほぼ同等であるが、耐熱性に劣る ため用途には限界がある。PBS 誘導体に打いてもコモノ マー組成が $3 \sim 5 \mathrm{~mol} \%$ であるめ、融点やガラス転移点 に大きな違いは見られないが、共重合体の繊維では強度が 低下する。一方、テレフタレート単位を含有する PBST、 PBAT、PEATではコハク酸単位やアジピン酸単位の含有 量に依存して性質は異なる。テレフタレート単位の多い PEAT は硬い性質を保つのに対して、その量が $50 \%$ 程度 となったPBST、PBATは柔らかい性質を示す。最近、Du Pont 社は PEAT $\left(\right.$ Maxon $\left.^{\circledR}\right)$ を繊維化して綿と混紡すること により、分解性の高いポリエステル/綿混紡系を上市して いる。従来の PET/綿混紡にかわる素材として注目される。

PBS の原料となるコハク酸とブタンジオールは、一般 的には石油から製造されているため、PBS は生分解性で はあるがバイオべース素材ではない。 life cycle assessment (LCA)による評価では、この石油由来の PBS を利用して も環境負荷に対する寄与がほとんど期待できないことが明 らかになっている20)。従って、デンプン等の再生可能資源 からコハク酸を製造するバイオ発酵プロセスが検討されて いる。コハク酸の還元によりブタンジオールも合成できる

表 6 ポリコハク酸ブチレン誘導体の性質

\begin{tabular}{|c|c|c|c|c|c|c|c|c|}
\hline & $\begin{array}{c}\text { コモノマー組成 } \\
(\text { Mol\% })\end{array}$ & $\begin{array}{c}\mathrm{Mn} \\
\left(10^{4} \mathrm{Da}\right) \\
\end{array}$ & $\mathrm{Mw} / \mathrm{Mn}$ & $\begin{array}{c}\mathrm{Tm} \\
\left({ }^{\circ} \mathrm{C}\right) \\
\end{array}$ & $\begin{array}{c}\mathrm{Tg} \\
\left({ }^{\circ} \mathrm{C}\right) \\
\end{array}$ & $\begin{array}{l}\text { 強度 } \\
(\mathrm{MPa}) \\
\end{array}$ & $\begin{array}{c}\text { 弾性率 } \\
(\mathrm{GPa})\end{array}$ & $\begin{array}{c}\text { 伸び } \\
(\%)\end{array}$ \\
\hline PBS & 0 & 4.4 & 2.5 & 114 & -34 & 540 & 1.8 & 94 \\
\hline PBSL & 3 & 5.7 & 2 & 111 & -33 & 490 & 1. 0 & 60 \\
\hline PBSCL & 5 & 3. 27 & 2 & 109 & -36 & 210 & 0.44 & 27 \\
\hline PBSC & 5 & 4. 41 & 1.2 & 100 & -34 & 90 & 0.47 & 39 \\
\hline
\end{tabular}


ため、PBSの完全バイオベース化を困ることも可能であ る。

例えば、牛の胃袋から単離されるActinobacillus succinogenes 菌体は、グルコースやキシロース、また、そ れらの混合物に対して優れた資化性を示し、高収率でコハ ク酸を生成する ${ }^{21)}$ 。同様に、コリネ菌を用いて古紙や木材 のような廃棄バイオマスを原料とするコハク酸発酵も報告 されている22)。このようにして、生合成されたコハク酸を 「バイオコハク酸」とよんでいる。コハク酸は C4 のカル ボン酸であるため、C 6 のグルコースから生合成されると きには 2 分子の炭酸ガスが発生することになる。しかしな がら、高圧の炭酸ガス䨌囲気で発酵を行うと、2 分子の炭 酸ガスが固定されて 1 分子のグルコースから 2 分子のコハ ク酸が得られる。この挙動は、炭酸ガス収支の観点から注 目を集めている。バイオコハク酸はポリマーを合成するモ ノマーとしてだけでなく、他の基礎化学品の出発物質とし て注目されており、バイオベース化学工業の基礎原料とな る可能性が高い。

\section{PTT 繊維}

Du Pont 社は、G3 とよばれるポリトリメチレンテレフ タレート (poly(trimethylene terephthalate): PTT)を開発 している ${ }^{23)}$ 。このポリマー自体は、新しいものではないが ジオール成分であるトリメチレングリコール (1,3Propanediol： 1,3-PD)をグリセリンやグルコースを原料に して発酵により生産できるため、原料・プロセスのバイオ ベース化が図れることが特徴となっている。一方、Shell 社をはじめとする数社は $1,3-\mathrm{PD}$ も石油化学プロセスで生 産して同じ PTTをつくることを提案している ${ }^{24)}$

PTT は生分解しないうえテレフタル酸の合成を石油化 学に依存しているため、1 部の原料がバイオべースになっ ているにすぎないが、表 7 に比較するように、これまでの PET P PBT と少し異なった性質を示すため、新しいポリ エステル繊維素材としてスポーツウェアなどに利用されて いる。

\section{0. バイオマス繊維による強化複合材}

セルロースやタンパクという高分子系バイオマスの多く は繊維状態で存在しており、その性状を強調する意味で、
表 7 テレフタレート系ポリエステル繊維の特性比較

\begin{tabular}{|l|rrr|}
\hline & \multicolumn{1}{|c}{ PTT } & \multicolumn{1}{c|}{ PET } & PBT \\
\hline 融点 $\left({ }^{\circ} \mathrm{C}\right)$ & 230 & 260 & 230 \\
ガラス転移点 $\left({ }^{\circ} \mathrm{C}\right)$ & 51 & 69 & 25 \\
比重 & 1.34 & 1.38 & 1.35 \\
引張強度 $(\mathrm{MPa})$ & $500-590$ & $550-720$ & 470 \\
弾性率 $(\mathrm{GPa})$ & 3.1 & 13.4 & 3.1 \\
伸度 $(\%)$ & $42-48$ & $30-38$ & $30-40$ \\
\hline
\end{tabular}

これらを「繊維性バイオマス」もしくは「バイオマス繊維」 (biomass fiber)とよぶことにした25)。表 8 に各種のバイオ マス繊維の特性を比較する。バイオマス繊維を直接利用す る試みの一つとして、繊維プラスチック複合材料(FRP)の 強化繊維として用いる例がある。ガラス繊維や炭素繊維の かわりにバイオマス繊維を利用することにより、使用後の 廃棄処理が可能になるだけでなく、生分解性ポリマーとの 複合化により完全生分解の可能な複合材料も開発される。 後者をバイオコンポジット(bio-composite) とよぶことがあ る。

短繊維状のバイオマスは、粉末としてポリマー中に練り 込まれるか、不織布としてポリマーを充填後固めて複合化 される。繊維としては麻がガラス繊維に匹敵する弾性率を 有するため最も有力視されているが、竹や莘の未利用繊維 の利用も考えられている。これについては、筆者の総説を 参照していただきたい ${ }^{26)}$ 。最近、トヨタ自動車は、ケナフ と PLLA 繊維を $70: 30$ の比で混合してマット状に成形し、

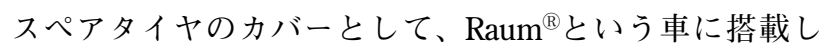
た27)。これはバイオコンポジットを実用化した最初の例で あり、PLLA 繊維はケナフの融着材として機能している。 この素材のライフサイクルアセスメントをみると、石油系 のプラスチック素材と比較して、90\%にのぼる二酸化炭 素削減が可能であるという。これを「カーボンニュートラ ル効果」とよび、環境保全への貢献をうたっている。

バイオマス繊維を複合材料の強化用繊維として利用する ときには、各繊維の特性だけでなく繊維と樹脂との界面接 着性について考慮しなければならない。特に、セルロース を主体とするバイオマス繊維は表面親水性が高く、疎水性 の強い樹脂との界面親和性が低下するうえ、バイオマス中

表 8 バイオマス繊維の特性

\begin{tabular}{|c|c|c|c|c|c|}
\hline 種類 & $\begin{array}{l}\text { 密度 } \\
\left(\mathrm{g} / \mathrm{cm}^{3}\right)\end{array}$ & $\begin{array}{c}\text { 引張弾性率 } \\
(\mathrm{GPa})\end{array}$ & 種類 & $\begin{array}{l}\text { 密度 } \\
\left(\mathrm{g} / \mathrm{cm}^{3}\right)\end{array}$ & $\begin{array}{c}\text { 引張弾性率 } \\
(\mathrm{GPa})\end{array}$ \\
\hline 大麻 (Hemp) & 1.50 & 12.7 & 竹 & $0.9-1.2$ & $21-38$ \\
\hline 亜麻(Flax) & 1.30 & $13-26$ & 孟宗竹 & 1.20 & 21.1 \\
\hline 黄麻(Jute) & 1.50 & $19-35$ & バナナ & 1.35 & $27-32$ \\
\hline ケナフ & 1.50 & $15-37$ & ココナッツ & 1.45 & 13.7 \\
\hline サイザル麻 (Sisal) & 1.45 & $16-37$ & 綿 & 1.50 & 11 \\
\hline 苧麻 (Ramie) & 1.50 & & ガラス繊維 & 2.50 & 70 \\
\hline
\end{tabular}


に含まれる微量の水分や代謝物由来の不純物がマトリック スポリマーの分解を引き起こして、熱成形性の低下を招く。 この微量成分は除去できないだけでなく、成形物の長期安 定性にも多大な影響を与える。バイオマス繊維との複合材 料を拡大するにはこの問題の解決が不可欠であろう。

\section{1. おわりに}

現在、資源問題、地球の温暖化等、種々の観点から、石 油原料ではなくバイオマス原料へシフトすることが考えら れるようになった。何よりも、昨今の原油価格の高騰がそ の動きを加速している側面が強い。PLLA P PTTなどの バイオベースポリマー・ファイバーの開発はその「さきが け」であろう。しかしながら、現在の技術ではバイオマス の利用には限界があり、その効率利用を進めるには新技術 の開拓、すなわち、21世紀の中核となるバイオ技術を利 用した大規模バイオインダストリー、あるいはバイオマス ベース産業の確立が重要となってくる。詳細については筆 者の近著を参考にしていただきたい28)。 「バイオべース」という新規領域は、基本的に、「資源・ 環境・エネルギー」に関する先導分野に属するが、バイオ テクノロジーやナノテクノロジー分野とも密接なつながり を有する境界領域分野である。大きなイノベーションを生 み出すであろうこの境界領域分野に対して、これまでに培 われた纎維技術が貢献できるところは多くあるように思わ れる。

\section{参考文献}

1）築島幸三郎、グリーンプラジャーナル、(11) ,5-7(2003).

2) R. Wedin, Chemistry, Spring 2004, P. 23-27

3）木村良晴、高分子、54(8)，576-577(2005).

4) S. S. Im, Y. H. Kim, J. S. Yoon, I. -J. Chin, Ed., "BioBased Polymers : Recent Progress" Macromol. Symp., 227, Wiley VCH (Weinheim), 2005.

5) R. P. Wool, X. S. Sun, "Bio-Based Polymers and Composites", Elsevier(London, UK) (2005).

6) T. Werpy and G. Petersen, "Top Value Added Chemicals from Biomass", The National Renewable Energy Laboratory \& DOE National Laboratory, 2004.

7）日本有機資源協会、「平成 15 年度バイオ生分解性素材 開発・利用評価事業報告書」、2004.

8）生分解性プラスチック研究会編、生分解性プラスチッ クハンドブック」、エヌ・ティー・エス(1995).
9）筏義人編著、「生分解性高分子の基礎と応用」、イピー シー、1999.

10）木村良晴、高分子、54(8)，576-577(2005).

11）筏 義人編：「ポリ乳酸一医療・製戍・環境のために 一」、高分子刊行会(1997).

12) L. Fambri, A. Pegoretti, R. Fenner, S. Incardona, C. Migliaresi, Polymer, 38, 79(1997).

13) Y. Furuhashi, H. Yamane, Y. Kimura, N. Yoshie, Fiber Prepr. Jpn 60 (1), 51(2005).

14) H. Yamane, K. Terao, S. Hiki, Y. Kimura, Polymer, 42, 3241 (2001).

15) Y. Doi, S. Kitamura, H. Abe, Macromolecules, 28, 4822 (1995).

16) T. Iwata, Y.Aoyagi, M. Fujita, H. Yamane, Y. Doi, Y. Suzuki, A. Takeuchi, K. Uesugi, Macromol. Rapid Commun., 25, 1100-1104(2004).

17）水谷章子、 $\mathrm{OHM} 、 2003 \cdot 11 、 44-45$.

18）前田昌宏、OHM、2003 $11 、 40-41$.

19) S. Nakano, A. El Salmawy, T. Nakamura, Y. Kimura, Sen'I Gakkaishi, 58(6), 209-215(2002).

20）染宮昭義：高分子、49(12), 822-825(2000).

21) J. Yi, M. V. Guettler, S. Kleff, M. D. Stowers, 27th Symposium on Biotechnology for Fuels and Chemicals, Denver (Colorado) 5-06, May 1-5(2005).

22) M. Inui, S. Murakami, S. Okino, H. Kawaguchi, A.A. Vertes and H. Yukawa, J Mol Microbiol Biotechnol. 7 : 182-196. (2004).

23) S. L.Haynie, L. W. Wagner, USP 5599689 (E. I. Du Pont de Nemours and Company, Wilmington, DE) 1995-0512.

24) H. H. Chuah, H. S. Brown, P. A. Dalton, International Fiber Journal (1995A) October.

25）木村良晴、「第 3 版䋊維便覧」、5.4.1 再生資源型䋊維 材料、丸善株式会社、874-878(2004).

26）木村良晴、近田英一、「ナノファイバーテクノロジー を用いた高度産業発掘戦略」、環境産業 3 繊維性バ イオマスと植物由来材料、シーエムシー出版、pp. 385395(2004)

27）築島幸三郎、グリーンプラジャーナル、2003-11、0507.

28）木村良晴、「高分子先端材料 5、天然素材プラスチッ ク」、共立出版 (2006). 